(and indeed the German Army Library Service was similar in many ways to our own). As an historical review it does not treat of the solutions which might have been used. But as far as it goes, Books for the Army does well a job that needed to be done.Herbert Goldhor, University of Illinois Library School.

\title{
Books About Printing and Bookmaking
}

Abriss der lateinischen Palaeographie. By Hans Foerster. Bern, Paul Haupt, 1949, 212p. Swiss Frank. \$20.00.

Mainzer Probedrucke. Ein Beitrag zur Gutenberg-Forschung. By Carl Wehmer. Munich, Leibnis-Verlag, 1948, 6op., I 2 illus. \$6.0o.

Gutenberg und der Weg des Abendlandes. By Konrad F. Bauer. Frankfurt A. M., Verlag der Goldene Brunnen, 1949, I8p.

Typographic Heritage. Selected Essays by

Lawrence C. Wroth. New York, The Typophiles, 1949, 162p. (Typophile Chapbook XX.)

The books selected here for review are each, in a different way, of interest to the scholarly librarian who likes to keep informed of progress in the history of printing and bookmaking.

The circle of men and women among librarians interested in the development of handwriting and the deciphering of medieval texts is not a large one, but it exists. Its members will be glad to learn of the appearance of Professor Hans Foerster's manual of paleography. In several regards this is a modest work. There are no plates or text illustrations; they were left out with the deliberate intention of keeping the price down. Also, the author is modest in his own approach to the many debatable questions in the field of Latin paleography. On each of these questions he takes great pains to acquaint the reader with every published opinion by every authority of rank and caliber. It cannot be said that this method promotes easy reading, and recognition of the bold outlines of evolution is not greatly facilitated thereby. But the presentation is a conscientious and fair one which leads the reader into the very midst of the stream of discussion and analysis. The English and American literature, it should be added, is not as familiar to the author as the continental European one. The significant study of Felix Reichmann on the book in ancient Rome and the studies of Stanley Morison and of H. S.
Steinberg on the late medieval writing master are not mentioned.

The strength of Hans Foerster's Abriss der lateinischen Palaeographie lies in the presentation of reasonably up-to-date knowledge in skillful condensation. The history of paleography as a discipline, the contribution of the important masters of the field and their publications, the various materials and forms of the written record, notes on the scribe, on the medieval book trade and on libraries, together with the detailed analysis of the evolution of the Roman alphabet in its various forms, make this a worthwhile book to own and to study.

Dr. Carl Wehmer's Mainzer Probedrucke contains sensational revelations to everyone who has followed serious research on the origin of European printing with movable type. Wehmer's study is based on the careful scrutiny of a small group of loose leaves, rescued from an unknown early binding, in the Jagellonian University Library in Cracow, previously described inaccurately as "Donatus Fragments." Actually, the leaves turn out to be simultaneous trial impressions of three different publications, one indeed a Donatus, the other one a trial proof of the so-called Astronomical Calendar for ${ }^{4} 448$ and the third a trial proof for a hitherto not recorded 40-line Bible project, all in the type, more or less, of the 36-line Bible. They are excellent, clean impressions, pulled on the loose pages of an old account book of a Mainz cloth merchant of the latter fourteenth century. Careful study of the type shows beyond doubt that the three projects for which these proofs were made were initiated after the securely dated "Tuerkenbulle" of 1456 . The seemingly unsurmountable difficulty which this discovery presents is the fact that the so-called Astronomical Calendar for 1448 (CW 1285) has been considered by its discoverer, Professor Zedler, and by every subsequent authority, as securely dated-on astronomical evidence-for the year 1448 . Therefore, it has been al- 
ways concluded it must have been produced sometime toward the end of I447. On this date and the state of the type used in this calendar, has been erected a whole elaborate chronological pyramid of early Mainz impressions. Forced by the new evidence of his discovery, Carl Wehmer is able to demolish this structure with one bold stroke: The 1448 calendar, he is able to show, was neither astronomical nor yet really a calendar. It was astrological in nature and intent, nothing more than a rather crudely calculated table of the planets in relationship to the phases of the moon. Therefore the calendar is in no way tied to the year 1448 which it happens to fit astronomically. It is difficult to see where Wehmer could be wrong in his essential argumentation. There is, of course, no room here for the detailed discussion of his excellent structure of reasoning.

$\mathrm{His}$ conclusions are startling but really quite simple: The Cracow trial proofs were made between 1457 and $I 459$ in Mainz by the anonymous printer of the Turk's Calendar, who was then planning a reprint of the 42-line Bible. $\mathrm{He}$ is probably identical with the man who moved to Bamberg and produced there the 36-line Bible. He was neither Gutenberg, nor Fust or Schoeffer. Editorially and artistically, his work is mainly popular and imitative in character, in striking contrast to the originality and the spiritual quality of Gutenberg's work.

It is difficult to see how, in the never-ending stream of Gutenberg studies, a really fresh evaluation of his contribution might be possible. Yet, this is precisely what Dr. Konrad F. Bauer, literary consultant of the Bauer Type Foundry and instructor of graphic arts in the new French-sponsored University of Mainz, has achieved. His Gutenberg und der $W$ eg des Abendlandes cuts loose from every romantic and sentimentally exaggerated evaluation of the printing press, which after all has done as much harm as good. Dr. Bauer sees a new importance of Gutenberg's invention as the starting point of modern industrial production. With the casting mould and the printing press, Gutenberg created two mass production processes dependent upon each other. He was the first to use the far-reaching discovery that "it was economically worthwhile to employ the most costly and delicate proc- esses in the creation of an original model if the end product therefrom could rapidly be produced by machine." It was also in the printing industry that for the first time in the history of manufacture the need for industrial standardization was felt. Eighteenthcentury printing saw decisive contributions in this direction at least a century earlier than any other branch of production. Thus it can be said that mechanization, division of labor and standardization were first developed in the printing industry.

The invention of printing is also the first topic dealt with in Lawrence C. Wroth's Typographic Heritage, the reprint of his opening address, "The Fifteenth Century Book," at the Pierpont Morgan Library Exhibition of the anniversary year 1940 . This volume, the twentieth in the Typophiles' series of chapbooks, handsomely printed by the Anthoensen Press, is a collection of various essays by the scholarly librarian of the John Carter Brown Library in Providence, R.I. Their assembly from different places in one volume brings together scattered contributions not easily located, and it lends continuity and new meaning to each unit. "The British Influence Upon American Printing," for instance, was originally an address made on occasion of the presentation of the gold medal of the American Institute of Graphic Arts to Stanley Morison in June 1946. It reviews the English forces that have made themselves felt from the very beginning of printing in English speaking North America down to the times of Stanley Morison and of ourselves, his contemporaries. The third article, "Corpus Typographicum," owes its origin to the preliminary spade work necessary for the writing of a chapter on the early printing press in Mr. Wroth's well-known Colonial Printer. He found it desirable to examine the entire series of seventeenth and eighteenth-century printing manuals, which he discovered, "comprises a single body of typographic lore, unified by the rules of practice contained in the first of them, Moxon's Mechanick Exercises."

"Benjamin Franklin: The Printer at Work" was one of the papers delivered in the course of the "Meet Dr. Franklin" Conference conducted by the Franklin Institute of Philadelphia in a series of meetings of the year I939-40. It is valuable in its concentration 
upon its theme, focusing close attention to all the various activities and contributions of Franklin's many-sided genius to the one great complex of activities which we today call the graphic arts industry.

The last article "The First Work with American Type," a logical sequence to the previous articles dealing with earlier aspects of printing, was originally published in 1924

\section{New List of State}

Author Headings for the Official Publications of the State of Washington. By Lena Lucile Tucker. Seattle, University of Washington Press, I950, 75p. \$1.50.

This list was begun in 1939 by a committee appointed by M. Ruth MacDonald, then chairman of regional groups for the Pacific Northwest, A.L.A. Division of Cataloging and Classification. It was found difficult to maintain uniformity with the work being done in different places without constant consultation, and after a number of changes in the committee members, Miss Tucker took over the task of compilation.

The list attempts to include official entries from the organization of the Territory of Washington in 1853 to the year 1947. The official names, given in straight form as listed in the laws, are used as entries. Information given under each entry (when available) consists of three parts: date of establishment and history, function and bibliographic references. Omitted are the many and varied committees of both houses of the legislature, schools, colleges and departments of the institutions of higher education. Under the headings ARMORY COMMISSIONS; BANKS; and Taxation, the history of the various changes in these agencies is given for the convenience of the user.

The entries are arranged alphabetically, letter by letter, in three alphabets: Washington (Ter.), Washington (State), and entries not preceded by Washington (State). Entries for institutions are interfiled with the official entries in their alphabetical places.

The usefulness of the Tucker list is readily seen when its entries are compared with those given in the Library of Congress Cata$\log$ of Books Represented by L. C. Printed Cards, Ann Arbor, 1942-46, and supplements, for the period covered. Under Washington as Mr. Wroth's contribution to "Bibliographic Essays. A Tribute to Wilberforce Eames." The entire volume of Mr. Wroth's essays, followed by an appreciative note by Paul A. Bennett, the guiding spirit of the Typophiles, is in itself a becoming tribute to one of America's greatest scholarly librarians.-Hellmut Lehmann-Haupt, New School for Social Research.

\section{Author Headings}

(Ter.), Tucker lists 65 entries and I9 "see" references, while L.C. lists 16 main entries, of which I I are given in Tucker, and eight "see" references not included in Tucker. For Washington (State), Tucker gives 447 main entries and 54I "see" references, while L.C. lists 212 main entries, of which 140 are given in Tucker, and 203 "see" references, of which 97 are given in Tucker (L.C. uses inverted form for 43 of these). Five entries given as "see" references in Tucker are used as main entries in L.C. Under entries not preceded by Washington (State), Tucker lists 16 main entries (all beginning with the word Washington) and three "see" references. Similar entries are found in the L.C. list, but since it is difficult to determine that these entries are for official publications, they have not been compared. This comparison gives an indication of the relative amount of aid that is available to documents catalogers and reference librarians working with $W$ ashington state documents from these two sources of information.

Although most of the rules, compiled by the Special Committee on State Author Headings of the A.L.A.'s Division of Cataloging and Classification as a guide for compilers of state-author headings lists ( $c f$. Markley, A. E.: Author Headings for the Official Publications of the State of Alabama, Chicago, 1948, p. 122-I23) have been followed, there have been some changes in this list. Although rule four states that the history of an agency should appear only under the latest name of the agency, and references should be made from earlier names to the latest name, Miss Tucker has preferred to give the authority for the individual entry and a statement of the date and agency it supersedes and of that superseding it (cf. "Washington (State). State board of 